\section{A bioética hermenêutica a partir hermenêutica crítica de Ricoeur}

Marchi, Neiva De

Psicóloga, doutora em Bioética pelo Centro Universitário São Camilo/SP, preceptora da Residência Médica na Rede Metropolitana de Saúde, Sarandi/Paranál e-mail: neiva.marchi@hotmail.com

\section{Ravagnani, Milton}

Advogado, jornalista, docente do Curso de Direito do Centro Universitário Ingá, Maringá/Pr

\section{Marchi, Daniel Catto De}

Médico, residente em clínica geral da Santa Casa de Maringál $\operatorname{Pr}^{3}$, Brasil.

PALAVRAS-CHAVE: Bioética, Hermenêutica, Bioética Hermenêutica.

O pensamento contemporâneo apresenta marcadamente uma transformação dos valores que anteriormente norteavam as relações humanas, e essas mudanças têm ocorrido no âmbito das convicções éticas e ontológicas do Ocidente. A proposta hermenêutica elaborada por Ricoeur tem se apresentado como a melhor das possibilidades de interpretação dos problemas e discursos singulares que envolvem a experiência humana. Este estudo, de natureza qualitativa, partiu de uma pesquisa bibliográfica realizada em diversas bases de dados e a análise da bibliografia levantada foi baseada na hermenêutica crítica de Ricoeur em seu conceito de apreensão do objeto pela dialética da compreensão e interpretação. $O$ exercício hermenêutico na Bioética, ou bioética hermenêutica, possibilita uma reflexão crítica da ação sobre os pressupostos éticos, antropológicos e socioculturais que se referem à saúde, ao meio ambiente e à vida na sociedade atual. Por meio da bioética hermenêutica, é possível refletir sobre os discursos particulares ou específicos e as diversas esferas de interesse, com aproximação entre os diversos discursos - da ética e da Medicina, da ética e da política, da ética e da economia -promovendo um novo contexto que contemple uma base comum de valores compartilhados por uma sociedade viva, que está sempre em projeto e em busca de realização. Eleva-se, devido a sua perspectiva dialógica, à condição de campo do conhecimento que possibilita uma experiência moral nova, de diferente filiação e projeção. O modelo hermenêutico de compreensão permite a estruturação de uma Bioética que preserve e respeite a ação humana, considerando o mundo que a permeia e dialoga com as exigências formais às quais está sujeita. Desta forma lhe dá solidez e legitimidade, tão necessárias para sustentar sua pretensão e aspiração de ser expressão válida da compreensão dos problemas do nosso tempo, sendo a um tempo, elemento de aproximação e distanciamento para compreender a própria natureza humana.

\section{REFERÊNCIAS}

[1] RICOEUR, Paul. Interpretação e Ideologias. Rio de Janeiro: Francisco Alves, 1990.

[2] Do texto à acção - ensaios de hermenêutica II. Tradução de Alcino Cartaxo e Maria José Sarabando. Portugal: Rés Editora, 1989.

[3] - O conflito das interpretações: ensaios de hermenêutica. Porto: Rés Editora, 1988.

[4] VILLARROEL, R. Bioética hermenéutica. Acta Bioethica, Santiago, v. 6, n. 1, p. 141-157, p. 141-157, jun. 2000 . Disponível em: $<$ http://www.scielo.cl/scielo.php?script=sci_arttext\&pid=S17 26- 569X2000000100011\&lng=es\&nrm=iso $>$. Acesso em: 8 ago. 2018.

[5] FERRER, José Jorge; ÁlvAREZ, Juan Carlos. Para fundamentar a bioética: teorias e paradigmas teóricos na bioética contemporânea. São Paulo: Edições Loyola, 2003. 